\title{
A DESJUDICIALIZAÇÃO E OS TABELIONATOS DE PROTESTO: A PROPOSTA DE EMENDA CONSTITUCIONAL 108 DE 2015 E 0 MULTI-DOOR COURTHOUSE SYSTEM
}

THE DISJUDICIALIZATION AND PROTEST NOTARY OFFICES: THE CONSTITUTIONAL AMENDMENT PROPOSAL 108 OF 2015 AND THE MULTI-DOOR COURTHOUSE SYSTEM

\author{
Debora Markman \\ Mário Lúcio Garcez Calil
}

\section{RESUMO}

O objetivo deste trabalho foi estudar a função socioeconômica dos tabelionatos de protesto, no contexto do sistema de múltiplas portas, surgido nos Estados Unidos, utilizado para justificar a Proposta de Emenda Constitucional número 108 de 2015, que se dirige a inserir, no Art. 5o da Constituição Federal, o dever do Poder Público de fomentar mecanismos extrajudiciais de resolução de conflitos de interesse, por meio de pesquisa bibliográfica e documental, de caráter qualitativo. Foi utilizado, na escrita, o procedimento dedutivo. Justificase a pesquisa, pela necessidade de se encontram alternativas mais céleres e econômicas à jurisdição.

Palavras-chave: Tabelionatos de Protesto. Sistema de Múltiplas Portas. Proposta de Emenda Constitucional número de 108 de 2015. 


\section{ABSTRACT}

The objective of this study was to study the socioeconomic function of protest notary offices, in the context of the multi-door system, which was created in the United States, used to justify Constitutional Amendment Proposal number 108 of 2015, which is intended to insert, in Art. $5^{\text {th }}$ of the Federal Constitution, the duty of the Public Power to foment extrajudicial mechanisms of resolution of conflicts of interest, through bibliographical and documentary research, of qualitative character. The deductive procedure was used in writing. The research is justified, due to the need for faster and more economical alternatives to the jurisdiction.

Keywords: Protest Notary Offices. Multi-door System. Constitutional Amendment Proposal number 108 of 2015.

\section{INTRODUÇÃO}

A busca de métodos e mecanismos alternativos de resolução de conflitos de interesse tem sido preocupação constante do Poder Legislativo no Brasil ao longo das últimas décadas. Nesse sentido é que se encontra em trâmite no Congresso Nacional a Proposta de Emenda Constitucional de número 108 de 2015.

Referida PEC se embasa no multi-door courthouse system, surgido nos EUA, a estabelecer uma série de mecanismos de filtragem das demandas, permitindo que somente aquelas que efetivamente necessitem do provimento jurisdicional alcancem o Judiciário. Um mecanismos que tem se mostrado eficiente nesse sentido é o foro extrajudicial.

A atividade notarial e registral que mais se aproxima diretamente das questões econômicas e negociais é a dos tabelionatos de protesto, encarregados de conferir publicidade, autenticidade, segurança e eficácia aos títulos e demais documentos representativos de dívida, evitando vários processos judiciais dirigidos à cobrança de valores.

O objetivo do presente trabalho foi estudar a função socioeconômica dos tabelionatos de protesto, no contexto do sistema de múltiplas portas utilizado para justificar a Proposta de Emenda Constitucional número 108 de 2015, por meio de pesquisa bibliográfica e documental, de caráter qualitativo. 
Utilizou-se, na escrita, o procedimento dedutivo. 0 trabalho foi divido em quatro partes. Na primeira foi tratadas a PEC 108 de 2015 e o denominado multi-door courthouse system. A seguir, foram estudas as funções socioeconômicas das serventias extrajudiciais: profilática; pacificadora; e desjudicializadora.

Na sequência, foi trabalhado o procedimento de protesto de títulos e outros documentos de dívida, a relação contratual/cambial e os títulos e documentos passíveis de protesto, o conceito de protesto extrajudicial, assim como o protesto por falta de pagamento, aceite ou devolução.

A seguir, foram estudadas as vantagens econômicas do protesto, o protesto como alternativa à jurisdição executiva, suas relações com a segurança jurídica, a igualdade, a economia, a prevenção e as facilidades na recuperação de créditos. Justifica-se a pesquisa, pela necessidade de se encontram alternativas mais céleres e econômicas à jurisdição.

\section{A PROPOSTA DE EMENDA CONSTITUCIONAL NÚMERO 108 DE 2015 E 0 MULTI-DOOR COURTHOUSE SYSTEM}

A Proposta de Emenda Constitucional de número 108, do ano de 2015, originária do Senado Federal, busca adicionar um novo dispositivo, de caráter aparentemente programático, ao extenso rol de direitos e garantias fundamentais presente no Art. 5o da Constituição Federal de 1988.

Dentre as justificativas para a referida propostas, de acordo com a mensagem que a apresenta aos demais legisladores, se encontra o denominado Multi-door Courthouse System, surgido no direito americano, de maneira que se faz necessário estudar o referido conceito e sua aplicabilidade no Brasil.

\section{A PEC 108 DE 2015}

De autoria do Senador Vicentinho Alves, a Proposta de Emenda Constitucional número 108, de 2015, se dirige à inserção de mais um inciso no Art. 5ํo da Constituição Federal, localizado após o último já 
existente, acrescendo, portanto, um direito ou garantia fundamental à esfera jurídica do cidadão.

O Art. 5o da Constituição passaria a vigorar acrescido de um inciso LXXIX, a determinar que "'[...] o Estado estimulará a adoção de métodos extrajudiciais de solução de conflitos”, justificado pelo aumento de processos judiciais e a falta de estrutura judiciária, que tornariam ineficaz o direito fundamental de acesso à Justiça (BRASIL, 2015, n.p.).

De acordo com o CNJ, em 1990, foram instauradas mais de 5 milhões de ações; em 2000, 12 milhões; em 2010, 24 milhões, enquanto os processos acumulados eram de, aproximadamente, 84,3 milhões, saltando, em 2011 para 90 milhões e, em 2013, para 120 milhões (BRASIL, 2015, n.p.).

Assim, a estrutura do Poder Judiciário, apesar do esforço de seus integrantes, "[...] não tem condições para acompanhar esse crescimento vertiginoso dos conflitos judiciais", já que o "culto ao litígio", é cultural no Brasil, "[...] justamente pela ausência de espaços institucionais voltados à comunicação de pessoas em conflito" (BRASIL, 2015, n.p.).

Para efetivar o direito fundamental de acesso à Justiça, o Estado deve fomentar "[...] a utilização de meios extrajudiciais de solução de conflitos" que, em sede constitucional, são implícitos. Assim, o objetivo da referida PEC é "homenagear esses meios alternativos de solução de conflitos e erigi-los à categoria de norma constitucional” (BRASIL, 2015, n.p.).

Relaciona a ideia ao Direito Comparado, especificamente, à criação do Sistema Multiportas (Multi-door Courthouse System) surgiu nos EUA, em 1976, em uma conferência proferida por Frank Sander, na Faculdade de Direito de Harvard, inspirado na insuficiência do Judiciário americano para atender ao crescente número de demandas (BRASIL, 2015, n.p.).

Trata-se, de acordo com a Mensagem, "[...] de um sistema que disponibiliza várias opções (várias 'portas') de solução de conflitos alternativamente ao Poder Judiciário" (BRASIL, 2015, n.p.). Em decorrência dessa referência, faz-se necessário entender do que se trata esse sistema, bem como as possiblidades de sua implantação no Brasil. 


\section{A MULTI-DOOR COURTHOUSE}

O Poder Legislativo brasileiro tem frequentemente tentado, ao longo das últimas duas décadas, criar e manejar instrumentos destinados ao desafogamento do Judiciário nacional, especialmente por meio de procedimentos desjudicializadores e preventivos da litigância. 0 modelo das "portas múltiplas", de criação americana, demonstra preocupação similar.

O Professor Frank E. A. Sander, da Harvard Law School, propôs um conceito voltado a ligar, de forma eficiente, os casos aos fóruns apropriados para os acordos, denominada Multi-Door Courthouse, ou Multi-Door Dispute Resolution Center, ou, simplesmente, Multi-Door Center (RAY; CLARE, 1985, p. 9).

Esse modelo ideal inclui um centro que oferece serviços sofisticados e sensíveis de admissão e uma variedade de atividades de resolução de disputas, sob o mesmo teto. Ali, a uma unidade de triagem caberia diagnosticar as disputas dos cidadãos e, depois, encaminhar os disputantes à "porta" apropriada para lidar com o caso (RAY; CLARE, 1985, p. 9).

Trata-se de um Tribunal de multitarefas, no qual uma variedade de agências, incluindo a polícia, promotores, tribunais, serviços jurídicos e agências de serviços sociais. Os oficiais de admissão tentariam resolver as queixas dos cidadãos durante o contato inicial, por meio de conciliação telefônica ou informações adicionais (RAY; CLARE, 1985, p. 9).

Caso o atendimento inicial não puder resolver assim o caso, os oficiais encaminhariam os cidadãos para o mecanismo de resolução de disputas mais apropriado disponível: arbitragem, mediação, conciliação ou adjudicação, que seriam institucionalizadas no sistema de justiça e estruturadas para atender às necessidades individuais (RAY; CLARE, 1985, p. 9).

A ideia tem cinco objetivos: aumentar a conscientização sobre a variedade de opções de resolução de disputas; ajudar os cidadãos a localizar os fóruns apropriados para suas disputas; auxiliar projetos de processamento de disputas na obtenção de referências de casos apropriados e aumentar a coordenação de serviços entre os fóruns (RAY; CLARE, 1985, p. 16) 
O objetivo comum dessas ideias é aumentar o conhecimento sobre as técnicas apropriadas para a triagem e combinar os casos específicos, para determinar os fóruns específicos a partir de pesquisas de avaliação. 0 quinto objetivo é incentivar a replicação de mecanismos centralizados de análise de disputas (RAY; CLARE, 1985, p. 16).

A implementação bem-sucedida desses objetos é capaz de melhorar a entrega e o acesso à justiça aos cidadãos (RAY; CLARE, 1985, p. 16). Trata-se assim, de um sistema formulado em camadas: um procedimento de resolução será utilizado somente caso o anterior falhe ou se demonstre inadequado à resolução do conflito.

Sander enxergou valor na disponibilidade de formas alternativas de resolver disputas. Esperava-se que, por meio de um tribunal de portas múltiplas, os cidadãos encontrassem uma justiça mais acessível, pois os réus e aqueles que não pudessem custeá-lo ou entende-lo, encontrariam alternativas mais acolhedoras (KESSLER; FILKENSTEIN, 1988, p. 578).

Esperava-se que os cidadãos se beneficiassem com técnicas que incentivassem os litigantes a elaborar seus próprios acordos e se beneficiarem da avaliação precoce dos casos, do processamento acelerado e da diminuição do formalismo, a tornar os processos mais compreensíveis (KESSLER; FILKENSTEIN, 1988, p. 578).

Desse modo, os litigantes poderiam resolver disputas com menos gastos, mais satisfação e menos acrimônia, por meio das alternativas acessíveis e viáveis ao processo adversarial, reduzindo o número de julgamentos e, consequentemente, o congestionamento nos calendários dos tribunais (KESSLER; FILKENSTEIN, 1988, p. 578).

0 processamento mais célere daria tempo aos juízes para se dedicarem aos casos que efetivamente requerem atenção e intervenção (KESSLER; FILKENSTEIN, 1988, p. 578), de modo que bem se adequa às expectativas legislativas nacionais voltadas à desjudicialização e à economia processual (financeira e de tempo).

Funciona, desse modo, como uma espécie de filtro das demandas, em diversas camadas, permitindo que apenas aqueles conflitos de interesse que necessitam do provimento jurisdicional de forma indispensável alcancem o Poder Judiciário, que se torna, nesse contexto, verdadeiramente, a última porta. 
No contexto das possibilidades de sua aplicação no Brasil, uma das "portas" que cada vez mais se abrem à população na resolução de conflitos (talvez a primeira delas) mostra-se no trabalho das serventias extrajudiciais, de notas e de registros públicos, especialmente no que concerne à pacificação mais célere, preventiva e barata dos conflitos.

\section{AS FUNÇÕES SOCIOECONÔMICAS DAS SERVENTIAS EXTRAJUDICIAIS}

Os ofícios extrajudiciais, comumente denominados "cartórios", são órgãos vinculados ao Poder Judiciário dos Estados, dirigidos por particulares, que prestam serviços mediante delegação do Poder Público, de acordo com as atribuições legalmente possíveis, mediante concurso público, de provas e títulos.

Suas atividades são reguladas pela Constituição, pela lei e pelas normativas nacionais e estaduais, e fiscalizadas pelo CNJ, pelas Corregedorias Gerais de Justiça dos Estados e pelos Juízes de Direito competentes para tanto. As atribuições dos serventuários extrajudiciais, além disso, demonstram importantes funções sociais.

\section{A FUNÇÃO PROFILÁTICA}

A primeira das funções sociais das serventias extrajudiciais é a profilática, voltada à prevenção de litígios, buscando a publicidade, autenticidade, segurança e eficácia dos atos colocados sob seu crivo, eliminando boa parte das possíveis contendas judiciais, ao mesmo tempo em que assegura a estabilidade das relações jurídicas.

A atividade jurisdicional atua na solução do litígio a posteriori, buscando resolver o conflito já instaurado, de modo que "[...] a certeza jurídica a posteriori é aquela que se obtém depois da ocorrência de um fato mediante a função jurisdicional, onde, por uma sentença definitiva, alcança-se a sua exatidão" (COMASSETTO, 2002, p. 68).

Já na atividade notarial fixa-se o direito a priori, “[...] uma vez que a certeza jurídica é atingida sem a necessidade de surgimento de um litígio. 
Sendo assim, constata-se que a atividade do tabelião tem por finalidade buscar a exatidão de forma preventiva, dotando os seus atos de fé pública e de autenticidade" (COMASSETTO, 2002, p. 68-69).

A profilaxia jurídica buscada pela atividade notarial e registral, desse modo, acaba por prevenir conflitos, amenizando o altíssimo grau litigiosidade contida presente no Brasil. Trata-se de uma das funções que se encontra no cerne jurídico desse serviço, e que deve guiar o trabalho dos serventuários.

Unido à necessidade de solucionar rapidamente, porém, sem o abandono da segurança nas relações, está o princípio da prevenção de litígios ou acautelamento, decorrente do crescimento exacerbado de provocações ao Judiciário, que fazem com que as demandas se acumulem, apesar dos esforços do Judiciário (CHAVES; REZENDE, 2013, p. 68).

Ligado à Justiça Notarial, pressupõe que o oficial atue "[...] de forma segura e cautelosa, procurando prevenir, sempre que possível, por meio do bom desempenho dos atos de sua competência, o futuro litígio" (CHAVES; REZENDE, 2013, p. 68), demonstrando que a atividade extrajudicial é, por natureza, preventiva e, especialmente, pacificadora.

\section{A FUNÇÃO PACIFICADORA}

Faz-se necessário esclarecer que a atividade das serventias extrajudiciais, mais do que prevenir litígios, volta-se a pacificar as relações particulares, inclusive aquelas de caráter econômico, como um dos derivativos do princípio da prevenção de litígios, podendo atuar, inclusive, após a instalação do conflito de interesses.

Além das garantias de segurança jurídica (ou em razão delas), a atuação notarial preventiva (antiprocessual) evita a sobrecarga de um Judiciário “[...] atolado nos problemas de falta de celeridade e de eficiência. 0 modelo de atuação do notariado latino procura instaurar e proteger a situação de normalidade" (CAMPILONGO, 2014, p. 22).

Aliás: “[...] no dizer premonitório de Carnelutti: menos notário e mais juiz. Poder-se-ia acrescer: menos consenso e mais conflito institucionalizado; menos normalidade e mais patologia; menos prevenção e mais repressão". 
São dois modelos de regulação úteis e legítimos, cada um com vantagens e desvantagens institucionais (CAMPILONGO, 2014, p. 22-23).

O Conselho Nacional de Justiça, por meio da Resolução n. 125 reconheceu que, além das técnicas públicas de mediação e conciliação, “[...] as fórmulas mistas ou mesmo privadas, isto é, realizadas fora do sistema judicial, até em escritórios privados, são perfeitamente admissíveis". (CAMPILONGO, 2014, p. 133)

Assim: “[...] os notários são conciliadores e mediadores por definição e antonomásia, é dizer, no mais alto grau e por excelência”. Ao contrário da jurisdição ordinária, a atuar em situações conflitivas, o notariado "[...] está na linha de frente das pressões econômicas e sociais" (CAMPILONGO, 2014, p. 142).

Por isso é que deve responder de forma imediata e próxima, cooperativa, consensual e reflexiva, o que "[...] reforça sua eficiência econômica e sua identificação com as estruturas de confiança" (CAMPILONGO, 2014, p. 160). Trata-se de uma característica do denominado sistema latino, no qual o notário é um profissional do direito dotado de fé pública.

No sistema anglo-saxônico, o notary ou public notary limita-se a identificar subscritores, reconhecer assinaturas e selar, como testemunha do ato (parol evidence ou testimony), não atuando como qualificador ou assessor jurídico. Qualquer pessoa pode ser investida na função, razão pela qual são desprovidos de fé pública (MORAES, 2014, p. 167).

Na União Europeia “[...] não chegam a uma para mil as ações judiciais cujas transações foram submetidas ao sistema notarial do tipo latino, como o brasileiro, enquanto nos Estados Unidos da América esse risco é cerca de cinquenta vezes superior, por conta do sistema da common law" (MORAES, 2014, p. 167).

Sob o argumento da celeridade e da redução dos custos, afirma-se que o comércio eletrônico prescindiria da qualificação dos delegatários. Ocorre que é justamente o oposto: "[...] quanto mais impessoal a transação, ainda maior há de ser o cuidado". Também nesse ponto os serviços notariais e de registro melhor garantem o mercado (MORAES, 2014, p. 167).

Assim, "[...] tanto mais valorizada e utilizada a atividade notarial e registral, menos há litígios e, logicamente, menor a necessidade de intervenção do Poder Judiciário", que terá mais tempo para resolver 
litígios não compostos (MORAES, 2014, p. 167), situação que demonstra sua função desjudicializadora.

\section{A FUNÇÃO DESJUDICIALIZADORA}

A terceira das principais funções socioeconômicas das serventias extrajudiciais é a de desjudicialização dos conflitos de interesse, que acaba por ser o resultado das funções profilática e pacificadora, mediante a qual os ofícios são capazes de desafogar o Poder Judiciário, tendo em vista que filtram as demandas, impedindo-as de alcançar o foro judicial.

A administração pública de interesses privados pode ser realizada judicialmente ou por órgãos públicos não pertencentes ao Judiciário. Essa preocupação se fundamenta na relevância e na repercussão que certos atos jurídicos têm com o meio social, carecendo de proteção por ultrapassarem a esfera privada, interessando à coletividade (COMASSETTO, 2002, p. 118).

Trata-se de "[...] uma categoria genérica de tutela administrativa, onde a jurisdição voluntária, bem como a atividade dos notários são consideradas como espécies deste gênero, ressalvando-se que a função notarial se realiza na esfera extrajudicial" (COMASSETTO, 2002, p. 119), de modo que é diretamente praticada pelas notários e pelos registradores.

Participam eles da administração pública dos interesses privados, praticando atos submetidos à sua responsabilidade, civil e criminal, sem, todavia, acarretar dispêndio aos cofres públicos, exercendo, ao contrário, múnus público, contribuindo com os interesses estatais, também, por meio de prevenção de litígios (CHAVES; REZENDE, 2013, p. 35).

Desse modo, a desjudicialização promovida pelas serventias extrajudiciais é, de início, administrativo-financeira, pois resulta em economia para o Poder Judiciário, já que não mais necessita resolver contendas para cujo deslinde não seja imperioso o provimento jurisdicional. Essa vantagem, contudo, também alcançam a iniciativa privada.

Nos negócios jurídicos nos quais há intervenção notarial, há menor número de lides, por haver uma atividade voltada à segurança jurídica $a$ priori. A atividade notarial aumenta a quantidade de negócios jurídicos por 
lhes dar certeza jurídica, porém, reduz proporcionalmente a litigiosidade (LOUREIRO, 2017, p. 106).

A intervenção notarial diminui a litigiosidade mesmo quando induz ao aumento de negócios jurídicos: na Espanha, o aumento na quantidade de instrumentos notariais associa-se ao aumento da litigiosidade civil (LOUREIRO, 2017, p. 106). Ocorre que esse processo também ocorre em relação à função típica da jurisdição.

A desjudicialização caminha como alternativa à "[...] complexa, onerosa e, por vezes, demorada movimentação da máquina judicial, representando tendência contemporânea de potencializar mecanismos extrajudiciais de resolução dos conflitos que garantam celeridade, eficácia e segurança jurídica (RODRIGUES, 2014, p. 2).

Cria vias alternativas e eficientes de resolução de conflitos, sem descurar do livre e permanente acesso ao Judiciário. Afeiçoa-se, assim, "[...] ao propósito do sistema do notariado latino a que a lei atribui um valor declarativo e um grau de certeza e segurança jurídicas reforçados, com destacada atuação preventiva" (RODRIGUES, 2014, p. 2).

Notável, portanto, a existência de um sem-número de vantagens na utilização dos serviços extrajudiciais em comparação ao Poder Judiciário. Uma das atribuições que melhor demonstra a adequação dessas atividades à desjudicialização, a atuar como uma das portas dentro do sistema referido pela PEC 108, é o tabelionato de protestos.

\section{O PROTESTO DE TÍTULOS E OUTROS DOCUMENTOS DE DÍVIDA}

0 protesto é um ato de natureza mista, tanto notarial quanto registral, localizado entre o privado e o público, que se volta, assim como o restante da atividade extrajudicial, a conferir publicidade, autenticidade, segurança e eficácia a negócios jurídicos, especificamente, contudo, a títulos de créditos (não pagos, não aceitos ou retidos) e a outros documentos de dívida.

Referidos títulos e documentos podem se referir a dívidas tanto de natureza privada quanto pública, tendo em vista que se permite o protesto, inclusive, de certidões de dívida ativa. Encontra-se, portanto, diretamente 
ligado a questões econômicas, motivo pelo qual tem lugar especial dentre os mecanismos de resolução de conflitos alternativos à jurisdição.

\section{RELAÇÃO CONTRATUAL/CAMBIAL E OS TÍTULOS E DOCUMENTOS PROTESTÁVEIS}

Necessário observar, de início, que o mercado trabalha com uma boa dose de confiança entre os negociantes, especialmente nas relações contratuais. Essa confiança, todavia, se traduz em institutos jurídicos especificamente concernentes às relações obrigacionais. Dentre os principais instrumentos de garantia se encontram os papéis representativos dos sinalagmas.

É preciso haver confiança para que um dos contratantes conclua sua parte no negócio e para que aceite que a outra conclua a sua, em outro momento, definido ou não: o crédito é apenas "[...] a afirmação de uma faculdade jurídica, sendo que seu lado oposto, isto é, seu anverso, é obrigação" (MAMEDE, 2006, p. 28).

Nessa medida, "o crédito de um é o débito de outro", sendo que a confiança pode ser moral, "[...] fruto do bom nome que o obrigado goze no mercado, onde afirma-se sua honestidade, o que leva, o contraente a aceitar que sua obrigação no ajuste seja concluída depois, vale dizer, aceitar-lhe o débito, conservando o crédito" (MAMEDE, 2006, p. 28).

A cártula é "[...] afirmação do direito do credor a uma prestação jurídica, assim como a afirmação da obrigação do devedor àquela mesma prestação". O protesto é o ato que a torna "de amplo conhecimento do mercado" (MAMEDE, 2006, p. 34), de maneira que, em tempos de crise econômico-financeira, torna-se instrumento indispensável de garantia negocial.

Documentos de dívida protestáveis são documentos ordinários, “[...] que comprovam obrigações certas, líquidas e exigíveis, e que, por expressa previsão legal e para o fim especificado em lei, podem ser protestados pelo Tabelião" (AMADEI, 2004, p. 85), tanto para possibilitar a cobrança contra os devedores acessórios quanto para dar publicidade à dívida. 
O conceito relativo a documentos de dívida não é trazido pela lei, cabendo à doutrina e à jurisprudência sua definição. Note-se, contudo, alargamento da compreensão normativa pelas Corregedorias Gerais de Justiça acerca da abrangência desse conceito, incluindo, nela, documentos que expressem dívida líquida, certa e exigível (BUENO, 2017, p. 32-36).

0 alargamento doutrinário, jurisprudencial e normativo do conceito de documento de dívida demonstra um aumento geométrico na confiança depositada nos tabelionatos de protesto, plenamente justificável, especialmente em decorrência da segurança e da celeridade que podem ser obtidas por intermédio desse procedimento.

\section{O CONCEITO DE PROTESTO EXTRAJUDICIAL}

Há algumas celeumas doutrinárias acerca do conceito, especialmente quanto à sua natureza jurídica. Seu conceito legal, determina que se trata de um ato formal e solene dirigido a provar a inadimplência e o descumprimento de uma obrigação originada de títulos ou outros documentos de dívida (BRASIL, 1997, n.p.), todavia, com uma multiplicidade de efeitos.

0 protesto, dentro das finalidades legais, é prova insubstituível da apresentação do título ao devedor: "[...] em muitos casos, o devedor nem sabe em mãos de quem se encontra o título, que, por isso, deve ser apresentado a ele, obrigatoriamente". Assim, a intimação feita pelo tabelionato é uma forma indireta de apresentação (COSTA, 2008, p. 227).

Se houver recusa parcial ou total de pagamento, o inadimplemento é presumido, pois o devedor poderá provar, após, que nada devia quando do protesto. Assim, "[...] não há prova absoluta e definitiva da inadimplência pelo ato oficial do protesto, muito menos solene". A prova absoluta é da apresentação; a da inadimplência é relativa (COSTA, 2008, p. 227).

É ato formal, pois atende certas formalidades legais, mas não é solene, pois nenhum ritual é necessário para sua existência (COSTA, 2008, p. 227), de modo que o conceito legal, ao se referir à solenidade, simplesmente destaca o caráter oficial do protesto, em nada se relacionando a ritualística alguma. 
É ato jurídico, público, extrajudicial, formal, unitário e misto, de procedimento solene, com uma característica probatória. De seu caráter público é deriva a oficialidade, a determinar que apenas o Tabelião ou seu substituto legal podem praticá-lo. Caso as formalidades não sejam cumpridas, poderá ser cancelado judicial ou administrativamente (BUENO, 2017, p. 37-46).

É ato misto, que compreende lavratura e registro. É ato notarial, e, também, registral, simultaneamente. Assim, não pode haver protesto meio registrado. 0 protesto persiste, mesmo após o cancelamento do registro, mas sem produzir efeitos, somente podendo ser mencionado em certidão a pedido do devedor ou por ordem judicial (BUENO, 2017, p. 46-48).

É ato da parte que o tabelião meramente formaliza, composto da intenção em demonstrar sua diligência ou a inércia do sacado ou devedor, somada à potencial lavratura (BUENO, 2017, p. 49-52). Volta-se, portanto, a dar publicidade tanto a uma dívida não paga quanto a um título carente de aceite ou de devolução.

O PROTESTO POR FALTA DE PAGAMENTO, ACEITE OU DEVOLUÇÃO

Apesar da ênfase dada ao protesto decorrente do inadimplemento de obrigação representado por título de crédito ou qualquer outro documento representativo de dívida, o procedimento é também cabível para os casos de falta de aceite ou de devolução de títulos compatíveis com estes procedimentos.

Assim, protesto é o ato voltado a comprovar o descumprimento de obrigação consubstanciada em títulos ou outros documentos de dívida, que pode ser, após a apresentação, sucedida de pagamento. Caso isso não ocorra, o ato e o registro do protesto não ocorrerão; terá se concretizado, porém, a finalidade à qual se dirige (BUENO, 2017, p. 27).

Em alguns casos, todavia, refere-se o protesto à falta de aceite ou à falta de devolução do título de crédito, se for esse o caso. Há outros, todavia, nos quais apenas se busca comprovar a existência de dívida. Assim, demonstra-se a existência de duas funções: conservatória de direitos e meramente comprobatória (BUENO, 2017, p. 29-31).

Desse modo, o protesto pode se dar apenas a título de acautelamento de uma relação creditícia, tanto quanto pode ser um requisito indispensável à exequibilidade de um título em relação a alguns devedores que se 
encontram na cadeia cambial. De uma forma ou de outra, demonstra forte cariz assecuratório.

O protesto extrajudicial é, assim, ato unitário, público e solene, provado por meio da apresentação de título ou outro documento de dívida, “[...] no tempo e lugar devidos, certificando descumprimento ou inadimplência de obrigação nele declarada, bem como falta ou recusa de aceite" (RITONDO, 2015, p. 3).

Retido o título pelo sacado, o protesto será efetivado pela apresentação da segunda via da letra de câmbio ou, no caso da duplicata, por meio de triplicata ou indicações, “[...] contendo os mesmos requisitos lançados pelo sacador ao tempo da emissão do título de crédito" (RITONDO, 2015, p. 5).

Será possível o protesto se o título for remetido ao sacado para aceite e não devolvido, tratando-se de duplicatas, letras de câmbio ou outros títulos que venham a ser criados comportando aceite (RITONDO, 2015, p. 5). Assim, por sua simplicidade procedimental para o credor e por sua versatilidade, demonstra ser instrumento jurídica e economicamente útil.

\section{AS VANTAGENS ECONÔMICAS DO PROTESTO DE TÍTULOS E OUTROS DOCUMENTOS DE DÍVIDA}

Dos vários tipos de demandas que congestionam o Poder Judiciário, as que mais se destacam, especialmente em decorrência de sua absurda quantidade, são relacionadas à cobrança de dívidas públicas e privadas. Também nesse sentido é que o protesto extrajudicial colabora com o desafogamento do Poder Judiciário.

É preciso, sem descurar da ineficiência da prestação Jurisdicional, “[...] encontrar meios extrajudiciais de recuperação dos créditos necessários a dar continuidade no cumprimento da função social decorrente da propriedade, dos contratos e da liberdade de iniciativa". Demonstra-se, aí, a pertinência do Protesto extrajudicial (FREITAS; VITA, 2017, p. 39).

Cumpre ressaltar que se trata de uma alternativa à execução judicial, ainda capaz de manter, todavia, a publicidade e a segurança jurídica inerentes às serventias extrajudiciais, atuando preventivamente e 
facilitando sobremaneira a célere recuperação de créditos, favorecendo a circulação do capital e todas as vantagens dela advindas.

\section{PROTESTO COMO ALTERNATIVA À JURISDIÇÃO EXECUTIVA}

Inicialmente, a publicidade conferida pelo protesto à dívida ou à carência de aceite ou devolução de título, bem como a restrição de crédito por ela ocasionada, na maior parte das vezes, pode ensejar a quitação do débito de forma infinitamente mais célere do que o processo judicial.

Os devedores, "[...] na maioria dos casos, sentir-se-ão compelidos a cumpri-las a fim de evitar o abalo ao crédito e perda de credibilidade em face das pessoas que com eles celebrem ou venham a celebrar contratos", independentemente de serem instituições financeiras, fornecedores, instituições públicas, pessoas físicas etc. (FREITAS; VITA, 2017, p. 37).

Assim, a atual conjuntura jurídico-econômica tem o protesto extrajudicial como instrumento alternativo apto a promover a redução da sobrecarga do Poder judiciário, diminuindo custos e tornando efetiva a prestação jurisdicional em relação àquilo que mereça maior atenção (FREITAS; VITA, 2017, p. 42).

Isso porque alcança uma célere, efetiva e menos onerosa recuperação extrajudicial dos créditos não adimplido. Assim, o agente econômico poderá cumprir sua função social, por estar amparado pela maior lucratividade de suas atividades, cumprindo obrigações, investindo na expansão da empresa e em novas tecnologias etc. (FREITAS; VITA, 2017, p. 43).

Como se vislumbrou acima, em relação ao credor, o protesto extrajudicial é um procedimento simples, que demanda apenas a apresentação do título ou documento representativo de dívida, e de alguns dados do devedor, para que o tabelião possa proceder à sua notificação para pagar em três (3) dias úteis, sob pena de registro do ato.

0 caráter conciliatório do protesto notarial é evidente, pois, o devedor, uma vez intimado, tem um prazo para cumprir a obrigação no tabelionato, o que demonstra um adequado nível de coercibilidade e publicidade, vez que pode procurar o credor e renegociar a dívida, situação oficializada pela retirada do título ou documento de dívida (MARCON, 2018, p. 120). 
Desse modo, evita que os Tribunais se tornem ferramentas nas mãos de maus pagadores, por meio da utilização "de recursos legalmente previstos para procrastinar débitos legítimos, exigíveis, líquidos e certos". Por intermédio do modelo de gestão privado, oferece maior dinamismo à atividade, elevando a qualidade do serviço (MARCON, 2018, p. 121).

Por meio do protesto, “[...] o sistema creditório é oxigenado, uma vez que o impacto na credibilidade do devedor perante as instituições financiadoras acarretado pelo protesto, faz com que os agentes econômicos saudáveis queiram rapidamente saldar seus débitos", impedindo que o Judiciário funcione como mero cobrador (MARCON, 2018, p. 121-122).

É instrumento eficaz e seguro de satisfazer os débitos constantes de títulos e documentos de dívida, ao arejar o Judiciário, promovendo a pacificação social fora do processo, por um operador do Direito imparcial e distante das partes, possibilitando satisfazer o crédito em relação a todos os inadimplentes da cadeia cambiária (MARCON, 2018, p. 126).

Trata-se de um poderoso instrumento de coerção indireta do devedor, que o compele a quitar seus débitos sem a burocracia do processo judicial já que, após o prazo, somente poderá pagar junto ao tabelionato, arcando com custas e emolumentos, todavia, fazendo com que o ato cesse de produzir efeitos.

\section{O PROTESTO, A SEGURANÇA JURÍDICA E A CELERIDADE}

Apesar da impressão de que as complexidades do processo judicial são capazes de produzir maior segurança jurídica aos atos dirigidos à cobrança de dívida, é necessário esclarecer que a estabilidade das relações é justamente um dos princípios da atividade das serventias extrajudiciais.

Os tabeliães de protesto previnem litígios econômicos "[...] porque dão autoridade, confiabilidade e segurança ao ato lavrado", afastando a incerteza que podem gerar atos particulares, e coibindo possíveis questionamentos sobre a validade do ato, eliminando demandas e conflitos judiciais (MORAES, 2014, p. 30).

Coaduna, assim, com a dinâmica das relações econômicas e jurídicas. Dentre os milhares de apontamentos de protesto, raríssimos são objeto de 
impugnação judicial, “[...] uma média de sete liminares a cada dez mil, das quais apenas 0,4 (uma para cada vinte e cinco mil) recebe cancelamento judicial definitivo" (MORAES, 2014, p. 59).

A clássica noção de protesto cambial como simples registro de recusa de aceite ou pagamento há muito tornou-se incompleta, pois, além dessa finalidade, adquiriu função nova e mais importante, convertendo-se em execução forçada, que impede o protesto abusivo e assegura e revigora o protesto normal (MORAES, 2014, p. 99).

Até porque o protesto mais lavrado é aquele referente ao inadimplemento, que somente pode ser recusado por motivo presente na lei cambial. Trata-se do único meio válido para que o portador possa exercer seus direitos de cobrança contra os devedores indiretos: sacador, endossantes e avalistas (MORAES, 2014, p. 155).

Com apurada análise jurídica, prudência, imparcialidade e eficiência, próprias dos notários e registradores há realmente uma “[...] economia descontaminada dos miasmas que abalam a confiança creditícia e dos custos dispensáveis". A economia, contudo, de nada adianta sem a certeza do afastamento do risco de negócios inválidos (MORAES, 2014, p. 167).

0 ato de protesto cambial é submetido a um profissional do direito preparado para analisar os requisitos fáticos e jurídicos que devem ser cumpridos para que aquele seja ultimado. Necessário reafirmar que os oficiais recebem suas delegações após aprovação em concurso público de provas e títulos.

Os princípios norteadores da atividade do tabelião de protestos perpassam, necessariamente, a análise da segurança jurídica, pois tem assumido um caráter de instrumento de equilíbrio nas relações econômicas, importante na pacificação social, contribuindo para que inúmeros casos sejam resolvidos entre as próprias partes (MARCON, 2018, p. 120).

O instituto promove a confiança do mercado e a segurança jurídica. O devedor terá a certeza de que pagará apenas o que deve e o credor recuperará os valores com maior celeridade e menor ônus (MARCON, 2018, p. 122), o que demonstra, mais uma vez, as vantagens do protesto em relação ao processo judicial, inclusive, no que concerne à segurança. 


\section{O PROTESTO, A IGUALDADE E A ECONOMIA}

A partir da segurança e da celeridade proporcionadas pelo protesto extrajudicial, é perceptível que o procedimento também se preocupa com a igualdade e com a economia processual, a corroborar a função acauteladora das serventias extrajudiciais, assim como a desjudicialização que proporciona.

Isso porque o protesto é, também, ato do tabelião, “[...] praticado mediante provocação da parte e com ativa participação desta”. Assim. a atribuição da autoria a um não exclui a atribuição do outro. Ao lavrar o protesto, o tabelião não é mero anotador, mas, sim, um profissional que dá ao protesto as características que a lei a ele atribui (BUENO, 2017, p. 56).

Os elementos a serem averiguados para a imputação da responsabilidade serão os mesmos. Assim, a pessoa que pratica o protesto é que responderá por danos eventualmente causados, “[...] tanto quanto faria se fosse por ela realizado, isso porque é o portador quem impulsiona inicialmente o procedimento ao requerer o protesto (BUENO, 2017, p. 57).

Ao qualificar o título ou o documento, o tabelião não se esquiva de enfrentar questões formais relativas a capacidade, representação, dentre outros (BUENO, 2017, p. 58), de maneira que sua função profilática inclui a fiscalização dos requisitos legais e fáticos, tanto quanto ocorre no processo judicial, todavia, de maneira célere e objetiva.

Mais do que isso, o empresário não é, de regra, contemplado com o benefício da assistência judiciária gratuita, situação que lhe impõe, além dos custos com advogados, a responsabilidade pelas custas judiciais. A atividade promovida pelo tabelionato de protesto age diretamente em face dessa problemática (FREITAS; VITA, 2017, p. 43).

Assim, "[...] o protesto extrajudicial assume a condição instrumental de redução da assimetria de informações, tal como das externalidades resultantes do inadimplemento" (FREITAS; VITA, 2017, p. 35), corroborando, dessa maneira, a necessária isonomia processual, ao diminuir os custos procedimentais para credores e devedores.

Relembre-se que grande parte dos títulos são apresentado a protesto por Pessoas Jurídicas, que não postulam perante os juizados especiais, de modo que se torna uma forma preventiva em relação aos ônus e ao 
desgaste de um processo judicial, que pode chegar à conclusão de que não há bens suficientes para satisfazer o crédito (MARCON, 2018, p. 120).

Mais uma vez é possível perceber que o procedimento de protesto extrajudicial apresenta mais vantagens do que o processo judicial executivo, inclusive, dispensando gastos desnecessários, facilitando até mesmo o trabalhos dos advogados, consultores e assessores jurídicos, assim como possibilitando uma notável economia de tempo.

\section{O PROTESTO E A PREVENÇÃO}

Um efeito resultante da publicidade conferida pela atividade extrajudicial é a exposição do devedor como mau pagador ao público em geral, situação capaz de lhe ocasionar imensos transtornos, seja pessoa física ou jurídica, pois representa um gigantesco obstáculo à continuidade da sua vida financeira.

O protesto prova, mediante segurança jurídica, "[...] de forma precisa, certa, isenta de dúvidas, digna de fé, autêntica, solene, formal, oficial, notarial, com a marca da fé pública”. Apesar de aparentar hostilidade ou maldição, é um meio simples, célere e eficaz para satisfazer boa parte dos títulos não honrados em seu vencimento (AMADEI, 2004, p. 60).

Assim, é remédio para o inadimplemento, ponto de saneamento dos conflitos de crédito cambial e para a prevenção de negócios futuros. Tem função de profilaxia jurídica. Assim, não é mero apêndice, mas, sim, “[...] integra a medula do sistema cambiário, com sua presença medicinal entre a vida e a morte dos títulos de crédito" (AMADEI, 2004, p. 186).

Seu cariz preventivo, assim, de maneira alguma representa quebra da segurança jurídica. Ao contrário, é capaz de corrobora-la nas relações privadas, já que se dirige ao adimplemento forçado das obrigações, por meio de um instrumental de coerção indireta, tornando desnecessária a cobrança judicial.

Assim, tem caráter preventivo ao evitar o ajuizamento de milhares de ações. A admissão do débito pelo notário é preferível a qualquer proposição jurisdicional, pois a formalização desses atos, de eficácia erga omnes, é 
necessária para que não deságuem no Poder Judiciário (MORAES, 2014, p. 160), prevenindo a instalação judicial do litígio.

Não somente o protesto previne a judicialização do litígio como pode evitar a formação de negócios jurídicos desvantajosos a uma das partes, já que é capaz de demonstrar, documentalmente, o fato de que determinado devedor não honrou um compromisso financeiro dantes firmado.

Mais do que isso, é instrumento seguro de aferição da credibilidade econômica da pessoa (física ou jurídica) por terceiros, respaldando-o a decidir a melhor forma de celebrar contratos ou não, "[...] se existir risco de inadimplemento que inviabilize o objetivo de contratar" (FREITAS; VITA, 2017, p. 35).

A permissão para protestar títulos extrajudiciais dotados de certeza, liquidez e exigibilidade implica reconhecimento de sua eficácia social como "[...] instrumento de publicização efetiva dos devedores inadimplentes, que com isso sofrerão restrições ao acesso do crédito" (FREITAS; VITA, 2017, p. 37).

Nesse contexto socioeconômico, marcado pela financeirização da economia, a publicização faz com que o inadimplemento repercuta negativamente, com a restrição do seu nome diante de outros agentes econômicos, que deixarão de ofertar crédito e condições negociais (FREITAS; VITA, 2017, p. 39).

Em uma análise de custo-benefício, essa situação “[...] induzirá o devedor a cumprir a obrigação, pois, os benefícios do adimplemento tornam-se mais vantajosos do que o efeito de persistir na violação do dever a que está obrigado", o que resulta na célere recuperação dos créditos publicizados pelo protesto (FREITAS; VITA, 2017, p. 39-41).

Destaque-se, portanto, que a simplicidade do procedimento de protesto de títulos e documentos de dívidas é diretamente proporcional à sua eficiência na recuperação de crédito, de maneira que, a partir dessa prática, somente as cobranças que se demonstrem inviáveis por via notarial chegarão ao Poder Judiciário, que se torna, de fato, a última porta. 


\section{AS FACILIDADES NA RECUPERAÇÃO DE CRÉDITO}

O derradeiro dentre os mais importantes papéis representados pelos tabelionatos de protesto no que concerne ao sistema de múltiplas portas é o fato de que o procedimento notarial é capaz de facilitar e agilizar a recuperação de crédito, justamente por ser um mecanismo de coerção indireta.

Isso porque estimula os devedores a pagarem suas dívidas, pelo temor de terem seus nomes "sujos na praça", situação que dificulta ou inviabiliza compras, financiamentos e outros atos comerciais, de modo que, em geral, optam por pagar suas dívidas quando intimados pelos tabelionatos de protesto (FISHER, 2016, n.p.).

É uma recuperação de crédito caracterizada pela segurança jurídica e pela fé-pública inerentes à atividade notarial e registral. Assim, “[...] os credores têm a certeza de que estão diante de um procedimento seguro, prestado por profissionais comprometidos com a sociedade e com a observância da legislação pátria" (FISHER, 2016, n.p.).

Note-se, portanto, que é um mecanismo que acelera o recebimento de títulos e documentos de dívida vencidos, em uma proporção muito maior do que se demonstra possível por intermédio do processo judicial, inclusive, por não possibilitarem dilações probatórias, procedimentais ou recursais.

Com o crescimento de sua popularidade, hoje, nos tabelionatos, há mais pagamentos do que protestos, de modo que não é mais possível negar o caráter saneador do procedimento. Note-se que cerca de metade dos títulos apontados são pagos antes mesmo do término do prazo legal (BUENO, 2017, p. 31-32).

0 abalo de crédito decorre diretamente da publicidade do protesto, ampliado pela remessa das certidões em forma de relação às entidades de proteção ao crédito e com a multiplicação de bancos de consulta gratuita disponibilizados pelos próprios tabeliães, por meio das entidades que os agrupam (BUENO, 2017, p. 69).

0 protesto tem se demonstrado um poderoso instrumento de recuperação de crédito e de desafogo do Poder Judiciário, eficaz para produzir os efeitos a ele atribuídos por lei, como o exercício do direito 
de regresso ou a possibilidade se requerer a falência do devedor, dentre tanto outros (BUENO, 2017, p. 138).

0 credor que opta pelo protesto ao invés da simples inscrição do nome do devedor nos cadastros de maus pagadores ou de proteção ao crédito, está certo de que o procedimento legal será observado, inclusive, em relação à intimação regular, de modo que a segurança do ato, inerente à atuação do tabelião estará sempre presente (BUENO, 2017, p. 139-140).

Nesse sentido, a força coativa indireta do protesto é maior do que a mera inscrição do nome do devedor nos cadastros de maus pagadores, ao mesmo tempo em que é menos onerosa do que o processo judicial, além de ser mais rápida do que ambos no que concerne ao recebimento, facilitando a continuidade da atividade do credor.

Se o agente econômico deixar de receber a contraprestação convencionada, "[...] coloca-se em risco a continuidade do seu exercício, e, como corolário, os benefícios sociais daí decorrentes (empregabilidade, encargos trabalhistas, previdenciários, tributários etc.)", afetando o equilíbrio de mercado e eficiência alocativa (FREITAS; VITA, 2017, p. 39).

Além disso, possibilita contratar colaboradores e “[...] entregar um produto com preço mais acessível e de maior qualidade ao consumidor final, ampliando, com isso, a própria demanda pelos seus produtos e serviços. Há evidente redução de externalidades e custos de transação" (FREITAS; VITA, 2017, p. 43).

A agilidade no recebimento auxilia na manutenção do capital de giro dos credores, especialmente das pessoas jurídicas, permitindo que colabore direta e indiretamente com a economia. Demonstra-se, portanto, que os tabelionatos de protesto, no contexto do sistema de postas múltiplas, demonstra-se um poderoso e efetivo mecanismo de filtragem de demandas. 


\section{CONSIDERAÇõES FINAIS}

A Proposta de Emenda Constitucional 108 de 2015, do Senado Federal, busca adicionar um dispositivo de caráter aparentemente programático ao Art. 5o da Constituição Federal de 1988. Dentre as justificativas para tanto está o denominado Multi-door Courthouse System, surgido no direito americano.

De autoria do Senador Vicentinho Alves, a PEC 108, em sua mensagem, afirma que, nas últimas duas décadas, apesar dos instrumentos destinados ao desafogamento do Judiciário nacional, o número de processo s judiciais somente cresce, de modo que o modelo das "portas múltiplas" poderia representar solução efetiva.

É um sistema em camadas, no qual um procedimento de resolução será utilizado caso o anterior falhe ou seja inadequado à resolução do conflito, de maneira que bem se adequa às expectativas legislativas nacionais de desjudicialização e economia processual. É algo como um filtro de demandas.

O sistema permite que somente os conflitos de interesse que realmente necessitam do provimento jurisdicional alcancem o Poder Judiciário, que se torna a última porta. No Brasil, uma das "portas" cada vez mais abertas à população para resolver conflitos é representada pelas serventias extrajudiciais, por ser mais célere, preventiva e barata.

Os denominados “cartórios”, são órgãos vinculados ao Poder Judiciário estadual, geridos por particulares que recebem delegação do Poder Público, de acordo com as atribuições legalmente possíveis a cada espécie de serventia, após concurso público de provas e títulos, cujas atividades são reguladas pela Constituição, pela lei e pelas normativas nacionais e locais.

Trata-se de um serviço com importantes funções sociais. A primeira delas é a profilaxia, voltada à prevenção de litígios, todavia, atentando à publicidade, autenticidade, segurança e eficácia dos atos, que elimina boa parte das possíveis contendas judiciais, assegurando, simultaneamente, a estabilidade jurídica.

Acaba, portanto, por prevenir conflitos e amenizar a litigiosidade contida, a demonstrar que a atividade notarial e registral é, naturalmente preventiva e pacificadora. A atividade das serventias extrajudiciais, mais 
do que prevenir litígios, pacifica relações particulares, inclusive após a instalação do conflito de interesses.

É uma característica do denominado sistema latino que o notário seja um profissional do direito dotado de fé pública, ao contrário do que ocorre em outros países. Demonstra-se aqui, portanto, sua função desjudicializadora dos conflitos de interesse, como resultado funções profilática e pacificadora.

Os ofícios extrajudiciais desafogam o Poder Judiciário ao filtrarem as demandas, impedindo-as de chegar ao foro judicial. Essa desjudicialização é tanto administrativo-financeira, relacionada à economia proporcionada ao Poder Judiciário, bem como à iniciativa privada, que poupa gastos com custas judiciais.

Alcança, portanto, a função típica do Poder Judiciário, situação que demonstra que há muitas vantagens na utilização dos serviços extrajudiciais em comparação ao Poder Judiciário. Um dos serviços extrajudiciais que melhor demonstra que essas atividades são adequadas à desjudicialização, é o tabelionato de protestos.

Essa serventia pratica atos de protesto, de natureza mista, notarial e registral, voltados a conferir publicidade, autenticidade, segurança e eficácia a negócios jurídicos, especificamente, a títulos e outros documentos de dívida, tanto de natureza privada quanto pública, diretamente ligado, portanto, a questões econômicas.

Em decorrência desses fatores, demonstra ter lugar especial dentre os mecanismos alternativos à jurisdição. Nesse sentido, o mercado trabalha com uma boa dose de confiança entre os negociantes, que se traduz em institutos jurídicos concernentes às relações obrigacionais, dentre os principais se encontram os papéis representativos das dívidas.

Em tempos de crise econômico-financeira, o protesto é instrumento de garantia negocial, para possibilitar a cobrança contra os devedores acessórios e para dar publicidade à dívida. Aliás, o alargamento doutrinário, jurisprudencial e normativo do conceito de documento de dívida demonstra um aumento na confiança depositada nos tabelionatos de protesto.

É uma situação plenamente justificável, em decorrência da segurança e da celeridade proporcionadas pelo procedimento, apesar de existirem algumas celeumas doutrinárias da natureza jurídica do protesto. 0 conceito 
legal, ao afirmar a solenidade do procedimento, apenas se volta a seu caráter oficial, não se referindo a qualquer tipo de excesso burocrático.

Um dos objetivos do protesto é dar publicidade a uma dívida não paga ou a um título carente de aceite ou de devolução, de modo que pode se voltar a acautelar uma relação creditícia ou representar o cumprimento de um requisito indispensável à exequibilidade de um título acerca de alguns devedores dentro da cadeia cambial.

Em decorrência de sua simplicidade procedimental e sua versatilidade é um instrumento jurídica e economicamente útil, pois dentre as várias modalidades de demandas que congestionam o Poder Judiciário, as que mais se destacam são as cobranças de dívidas, de modo que o protesto extrajudicial auxilia no desafogamento do Poder Judiciário.

Cumpre ressaltar que se trata de uma alternativa à execução judicial, ainda capaz de manter, todavia, a publicidade e a segurança jurídica inerentes às serventias extrajudiciais, atuando preventivamente e facilitando sobremaneira a célere recuperação de créditos, favorecendo a circulação do capital e todas as vantagens dela advindas.

Inicialmente, a publicidade conferida pelo protesto à dívida ou à carência de aceite ou devolução de título, bem como a restrição de crédito por ela ocasionada, na maior parte das vezes, pode ensejar a quitação do débito de forma infinitamente mais célere do que o processo judicial.

No que concerne ao credor, o protesto extrajudicial é um procedimento simples, que demanda somente a apresentação do título ou do documento representativo de dívida e de alguns dados do devedor, de modo que o tabelião possa notifica-lo para pagar em três (3) dias úteis, sob pena de registro do protesto.

É um instrumento de coerção indireta, que compele o devedor a quitar seus débitos sem a burocracia do processo judicial. Mais do que isso, a impressão de que as complexidades do processo judicial produzem maior segurança jurídica não é real, já que a estabilidade das relações é um dos princípios basilares da atividade das serventias extrajudiciais.

Não bastasse, o ato de protesto cambial é submetido a um profissional do direito que analisa seus requisitos fáticos e jurídicos, situação que mais uma vez demonstra as vantagens do protesto. A segurança e a celeridade 
proporcionadas pelo procedimento fazem perceber que se preocupa com a igualdade e com a economia processual.

Além disso, dispensa gastos desnecessários, facilitando o trabalhos dos advogados, consultores e assessores jurídicos. A publicidade conferida pela atividade extrajudicial expõe o devedor como mau pagador ao público, causando-lhe transtornos e criado obstáculos à sua vida financeira, ao mesmo tempo em que corrobora a segurança jurídica.

Assim, a simplicidade do procedimento é diretamente proporcional à sua eficiência na recuperação de crédito. Assim, apenas as cobranças inviáveis por via notarial chegarão ao Poder Judiciário, que se torna a última porta, a demonstrar que o tabelionato de protestos é um importante mecanismo de filtragem de demandas.

\section{REFERÊNCIAS}

AMADEI, Vicente de Abreu. Princípios de protesto de títulos. In: DIP, Ricardo. (coord.). Introdução ao direito notarial e registral. Porto Alegre: IRIB, 2004. p. 69-113.

BRASIL. Lei 9492. 1997. Disponível em: <www.planalto.gov.br>. Acesso em: 29 jan. 2019.

BRASIL. Senado Federal. Projeto de Emenda Constitucional 108. 2015. Disponível em: <www.senado.leg.br>. Acesso em: 29 jan. 2019.

BUENO, Sérgio Luiz José. Tabelionato de protesto. 3 ed. São Paulo: Saraiva, 2017.

CAMPILONGO, Celso Fernandes. Função social do notariado: eficiência, confiança e imparcialidade. São Paulo: Saraiva, 2014.

CHAVES, Carlos Fernando; REZENDE, Afonso Celso. Tabelionato de notas e o notário perfeito. 7. ed. São Paulo: Saraiva, 2013.

COMASSETTO, Miriam Saccol. A função notarial como forma de prevenção de litígios. Porto Alegre: Norton, 2002.

COSTA, Wille Duarte. Títulos de Crédito. 4.ed. Belo Horizonte: Del Rey, 2008. 
FISHER, José Flávio Bueno. A função econômica do protesto: sua efetividade na recuperação de crédito. 2016. Disponível em: <http://www.notariado.org. br> Acesso em: 29 jan. 2019.

FREITAS, Matheus Silva de; VITA, Jonathan Barros. A eficiência alocativa do tabelionato de protesto à luz da análise econômica do direito. Economic Analysis of Law Review, v. 8, n. 2, p. 22-46, jul.-dez., 2017.

KESSLER, Gladys; FILKENSTEIN, Linda. The Evolution of a Multi-Door Courthouse. Cath. U. L. Rev. n. 37, p. 577-590, 1988.

LOUREIRO, Luiz Guilherme. Registros públicos: teoria e prática. 8. ed. Salvador: Editora Juspodivm, 2017.

MAMEDE, Gladston. Títulos de crédito. 3. ed. São Paulo: Atlas, 2006.

MARCON, Gabriela Almeida. Função social do protesto extrajudicial dos títulos e outros documentos de dívida no Brasil. Revista da AGU, v. 17, n. 03. 107-128, jul.-set., 2018.

MORAES, Emanoel Macabu. Protesto notarial: títulos de créditos e documentos de dívidas. 3 ed. Rio de Janeiro: Lumen Juris, 2014.

RAY, Larry; CLARE, Anne. The Multi-Door Courthouse idea: building the courthouse of the future... today. Journal on dispute resolution, v. 1, n.1, p. 7-54, 1985.

RITONDO, Domingo Pietrangelo. Protesto extrajudicial. Rio de Janeiro. Elsevier, 2015.

RODRIGUES, Marcelo Guimarães. Tratado de registros públicos e direito notarial. São Paulo: Atlas, 2014.

Recebido em: 05-02-2019

Aprovado em: 26-10-2020 


\section{Debora Markman}

Doutoranda em Ciências Sociais (UNICAMP). Mestre em Direito pela Universidade Metodista de Piracicaba (UNIMEP). Especialista em Advocacia Trabalhista pela Escola Superior de Advocacia (ESA/OAB - FUMEC). Especialista em Direito do Trabalho, Direito Previdenciário e Direito Constitucional pela Faculdade Dom Alberto. Pós-Graduanda em Direito Corporativo e Compliance pela Escola Paulista de Direito (EPD). Bacharel em Direito pela Universidade Presbiteriana Mackenzie (MACKENZIE). Professora de Direito Previdenciário na Universidade Presbiteriana Mackenzie - CCT e Docente da Faculdade Anhanguera de Valinhos (FAV). Licenciada por meio de Obtenção de Novo Título, expedida pela Fundação de Educação para o Trabalho de Minas Gerais (UTRAMIG). Doutora em Odontologia na área de Implantodontia pelo Centro de Pós-Graduação São Leopoldo Mandic de Campinas (SLMANDIC). Mestre Profissional em Odontologia pelo mesmo Centro de Pós-Graduação. Especialista em Periodontia, Implantodontia e em Prótese pela Faculdade de Odontologia e Centro de Pós-Graduação São Leopoldo Mandic. Especialista em Farmacologia pela Universidade Federal de Lavras (UFLA). Bacharel em Odontologia pela Pontifícia Universidade Católica de Minas Gerais (PUC MINAS). E-mail: deboramark@icloud.com

\section{Mário Lúcio Garcez Calil}

Pós-doutorado (bolsista PDJ-CNPQ) e estágio pós-doutoral (bolsista PNPDCAPES) pela Fundação de Ensino Eurípides Soares da Rocha, sob supervisão do Professor Titular Emérito Oswaldo Giacoia Júnior e do Professor Titular Horácio Wanderlei Rodrigues. Doutor em Direito pela Faculdade de Direito de Bauru (CEUB-ITE). Mestre em Direito pelo Centro Universitário Toledo (AraçatubaSP), aprovado com distinção. Especialista em Direito Público. Especialista em Direito Processual. Bacharel em Direito pela Universidade do Estado de Minas Gerais - UEMG. Professor Associado V da Universidade Estadual de Mato Grosso do Sul, Unidade Universitária de Paranaíba (graduação e pós-graduação), tendo sido coordenador do Núcleo de Prática Jurídica da instituição. Ex-professor colaborador do Programa de Mestrado em Direito da Fundação de Ensino Eurípides Soares da Rocha. Foi Professor, de março de 2007 a maio de 2010, das Faculdades Integradas de Paranaíba (FIPAR).E-mail: mario.calil@yahoo.com.br

Universidade Estadual de Mato Grosso do Sul, Unidade Universitária de Paranaíba.

Rua João Rodrigues de Melo, s/no

Jardim Santa Mônica

Paranaíba, MS 79500000 
